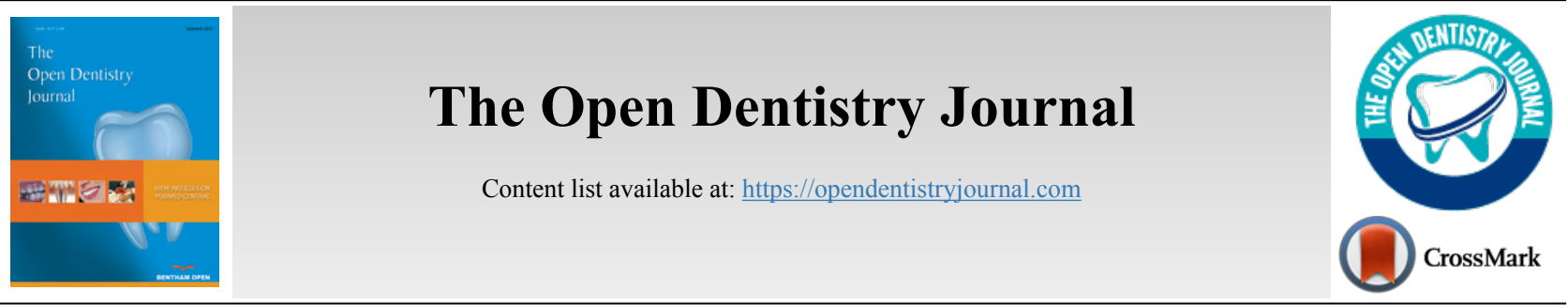

RESEARCH ARTICLE

\title{
Attitudes toward Social Media among Practicing Dentists and Dental Students in Clinical Years in Saudi Arabia
}

Khalid Aboalshamat ${ }^{1, *}$, Sharifah Alkiyadi ${ }^{2}$, Sarah Alsaleh ${ }^{3}$, Rana Reda ${ }^{3}$, Sharifa Alkhaldi ${ }^{2}$, Arwa Badeeb ${ }^{3}$ and Najwa $\mathrm{Gabb}^{3}$

${ }^{1}$ Dental Public Health Division, Department of Preventative Dentistry, College of Dentistry, Umm Al-Qura University, Makkah, Saudi Arabia ${ }^{2}$ Armed Forces Hospital, Dhahran, Saudi Arabia

${ }^{3}$ Private Practice, Jeddah, Saudi Arabia

\section{Abstract: \\ Background:}

Recently, social media use has been rising among dental students and practitioners.

\section{Objective:}

The aim of this study was to investigate the usage, attitudes, and professionalism on social media among dental students and dentists in Saudi Arabia.

\section{Methods:}

This cross-sectional study investigated 779 dental students, interns, and dentists recruited from university hospitals and private clinics in three major cities (Jeddah, Riyadh, and Dammam), representing the eastern, central, and western regions of Saudi Arabia. Validated questionnaires were distributed to the participants asking about the use of social media for general purposes and professional purposes, attitudes on the social media, professionalism on social media, and the use of social media for marketing purposes. This study was ethically reviewed and approved by the Faculty of Dentistry Institutional Review Board, Umm Al-Qura University with application number (102-18).

Results:

Among the participants, the social media platforms most frequently used on a weekly basis are WhatsApp $(\mathrm{m}=6.13$ days/week, $\mathrm{SD}=2.10)$, Snapchat $(\mathrm{m}=5.33, \mathrm{SD}=2.65)$, and Instagram $(\mathrm{m}=4.63, \mathrm{SD}=2.84)$. LinkedIn was the least frequently used platform. The most common professional uses were to watch clinical procedures $(80.49 \%)$, find new information $(79.59 \%)$, learn from peers $(61.1 \%)$, and communicate with patients (5.76\%). Only $47.75 \%$ followed their university or workplace professionalism guidelines, and $31.74 \%$ do not have any professionalism guidelines for using social media. There were $28.75 \%$ of participants who had considered posting information/photos about a patient without the patient's permission, those who had criticized a dental colleague numbered $49.04 \%$, and $59.69 \%$ had criticized a dental organization. However, only a few items had statistically significant differences between dental students and dentists.

\section{Conclusion:}

More stringent guidelines regarding proper conduct online should be implemented and included in the dental continuous education material.

Keywords: Social media, Attitude, Professionalism, Dental students, Dentists, Saudi Arabia.

\begin{tabular}{|l|l|l|l}
\hline Article History & Received: January 15, 2019 & Revised: February 24, 2019 & Accepted: March 19, 2019
\end{tabular}

\section{INTRODUCTION}

Social media can be defined as 'websites and applications

\footnotetext{
* Address correspondence to this author at the Dental Public Health Division, Department of Preventative Dentistry, College of Dentistry, Umm Al-Qura University, Taif Road, 21955, Makkah, Saudi Arabia; Tel: +966 12527 0000; E-mail: ktaboalshamat@uqu.edu.sa
}

that enable users to create and share content or to participate in social networking $[1,2]$. It consists of various types of platforms such as Facebook, Twitter, and media sharing sites like YouTube and Instagram. In recent years, social media use by health care providers has risen substantially [3]. In addition, social media applications have increasingly influenced the 
educational and learning processes [4] by, for instance, assisting students in seeking information regarding health care more easily and efficiently [5]. Recent studies have described widespread social media use among the students that involves more than one application. Facebook has been reported to be the most commonly used platform among dental students ranging between $91 \%-98.9 \%$ in the United States and the United Kingdom, at $91.0 \%$ and $98.9 \%$, respectively [6 - 8]. YouTube and Instagram were the second most used, and Twitter showed less popularity among dental students in the United Kingdom [8]. In the United States, Google+, Twitter, and LinkedIn were the less favored [7]. Some students have reported accessing YouTube to view videos of dental procedures before they are scheduled to perform it $[9,10]$. Students are generally using Skype and YouTube to improve educational skills, while Twitter and blogging sites are used to enhance communications and to allow for conversations between instructors and students [4].

Social media is also being used by doctors to distribute and spread knowledge acquired through treating patients and working with colleagues and other health care workers; in addition, postings can be made for workshop and conference announcements [4]. In a study conducted in South Africa, Google+ and Facebook scored the highest percentage of use among dentists, who used the platforms mainly for personal purposes [11]. Another study also showed Facebook to be the most popular site in the United States among respondents, with 97\% usage, followed by LinkedIn at $38 \%$ and Twitter with $32 \%$ [12]. The reasons given for using social media mostly fell into two categories, either marketing $(91 \%)$ or patient communication (73\%) [12]. In contrast, social media use as a marketing tool was reported by only $13.2 \%$ of the respondents in a South African study, but the same study indicated that this figure is expected to increase in the near future up to around $83.5 \%$ [11]. In the United Kingdom, one study showed that more than half of dentists had accounts for their dental practice on multiple social media websites [13]. Interestingly, more than two-thirds of dentists believed that social media networks are more effective than conventional marketing methods [13]. It should be noted that a previous study in the UK showed that dental students lack knowledge about legal regulations and need more guidance about professional use of social media, and the study recommended implementation of training for these students on the proper uses of social media [8].

Only one study investigated social media among health profession students in the Kingdom of Saudi Arabia (KSA), and it found that YouTube was the most frequently used social media site among medical students in the KSA, reaching $42.3 \%$ for both genders [14]. In addition, in the same study, Twitter was favored by males, while females chose social media apps to update their practical knowledge. Concerning learning, $95.8 \%$ of the students agreed that social media was tremendously useful [14]. However, no similar study has investigated specifically the dental profession or dental students.

The main aim of this study was to further investigate attitudes about social media among dental students and dentists in the KSA.

\section{MATERIALS AND METHODS}

This cross-sectional study investigated the usage, attitudes, and professionalism of dentists and dental students toward social media in Saudi Arabia. The participants were recruited from dental colleges located in three major cities in Saudi Arabia: Jeddah, Riyadh, and Al-Dammam. The quota sampling technique was used to ensure equal distribution between dentists and dental students. Saudi dentists or dental students who worked or studied outside of Saudi Arabia were excluded. By conducting a sample size calculation with a confidence level of $90 \%$, the estimated prevalence of $50 \%$, and precision level of $5 \%$, it was determined that the minimum number of participants required for this study was 271 . The hard copy questionnaire was distributed face to face to the target population by the research team during participants' break times during work or school. The questionnaire was collected immediately after they finished, with the completion time being approximately 5 minutes.

The questionnaire was derived from modifications to previous studies [6, 13, 15 - 18]. It was composed of four sections: The first section contained six demographic questions, including gender, age, specialty area of practice, and work region. The second section was composed of six questions measuring the general use of social media among the selected sample. The third part consisted of three major questions with multiple statements to determine the principles of professionalism in using social media. Finally, the fourth part included one question with multiple statements as answers meant to assess the role of social media in marketing. The types of answers varied and included Yes/No answers, selection of the most appropriate answer from several options, and those where all applicable answers could be selected.

The statistically significant level was set at 0.05 . Data analysis was conducted with SPSS v21 (IBM Corp., Armonk, NY, USA), and the tests used were Chi-squared, t-test, ANOVA, and linear regression. This study was ethically reviewed and approved by the Faculty of Dentistry Institutional Review Board, Umm Al-Qura University with application number (102-18). All participants signed the study consent before participating in the study. The study consent included all information about this study including the participant rights such as the ability to withdraw from the study at any time with any consequences, and that participation in the study is voluntarily and will not affect their relation with the author of the study by any mean. and All data were anonymous, to protect participants' confidentiality.

\section{RESULTS}

Data from the responses of 779 dental students and dentists were obtained. Participants' mean (m) age was 26.06 years with a Standard Deviation (SD) of 6.13. There were 438 $(56.2 \%)$ dental students and $341(43.8 \%)$ dental interns or dentists. The demographic data for the participants are shown in Table $\mathbf{1}$. 
Table 1. Demographic data.

\begin{tabular}{|c|c|c|c|}
\hline \multicolumn{2}{|r|}{ - } & Count & $\%$ \\
\hline Gender & Male & 359 & $46.1 \%$ \\
\hline- & Female & 420 & $53.9 \%$ \\
\hline Specialty & Dental student & 438 & $56.2 \%$ \\
\hline- & Dental intern & 165 & $21.2 \%$ \\
\hline- & General dentist & 78 & $10.0 \%$ \\
\hline- & Specialist & 76 & $9.8 \%$ \\
\hline- & Consultant & 22 & $2.8 \%$ \\
\hline $\begin{array}{l}\text { Main area of } \\
\text { practice }\end{array}$ & Private clinic/university & 598 & $76.8 \%$ \\
\hline- & Governmental clinic/university & 181 & $23.2 \%$ \\
\hline Work region & Central & 171 & $22.0 \%$ \\
\hline- & Western region & 530 & $68.0 \%$ \\
\hline- & Eastern region & 78 & $10.0 \%$ \\
\hline $\begin{array}{l}\text { Where do you } \\
\text { study or work? }\end{array}$ & Ibn Sina National College & 173 & $22.2 \%$ \\
\hline- & Alfarabi Dental College & 125 & $16.0 \%$ \\
\hline- & Batterjee Dental college & 189 & $24.3 \%$ \\
\hline- & King Abdulaziz University & 95 & $12.2 \%$ \\
\hline- & Riyadh Elm University & 101 & $13.0 \%$ \\
\hline- & $\begin{array}{c}\text { Imam Abdulrahman bin Faisal } \\
\text { University }\end{array}$ & 64 & $8.2 \%$ \\
\hline- & Private Clinic & 8 & $1.0 \%$ \\
\hline- & Other & 24 & $3.1 \%$ \\
\hline
\end{tabular}

Table 2. Personal reasons for using social media in general.

\begin{tabular}{|c|c|c|c|c|}
\hline- & - & \multicolumn{2}{|c|}{ Current Position } & Total n (\%) \\
\hline- & - & $\begin{array}{c}\text { Dental } \\
\text { Student (\%) }\end{array}$ & $\begin{array}{c}\text { Intern/ } \\
\text { Dentist (\%) }\end{array}$ & - \\
\hline $\begin{array}{c}\text { Finding useful } \\
\text { Information }\end{array}$ & Yes & $82.19 \%$ & $78.59 \%$ & $628(80.62 \%)$ \\
\hline- & No & $17.81 \%$ & $21.41 \%$ & $151(19.38 \%)$ \\
\hline Socializing & Yes & $68.95 \%$ & $63.05 \%$ & $517(66.37 \%)$ \\
\hline- & No & $31.05 \%$ & $36.95 \%$ & $262(33.63 \%)$ \\
\hline $\begin{array}{c}\text { Sharing photos, } \\
\text { files, music, videos }\end{array}$ & Yes & $70.32 \%$ & $62.76 \%$ & $522(67.01 \%)$ \\
\hline- & No & $29.68 \%$ & $37.24 \% *$ & $257(32.99 \%)$ \\
\hline Sharing ideas & Yes & $45.89 \%$ & $45.16 \%$ & $355(45.57 \%)$ \\
\hline- & No & $54.11 \%$ & $54.84 \%$ & $424(54.43 \%)$ \\
\hline $\begin{array}{c}\text { For business (buy } \\
\text { or sell general } \\
\text { goods). }\end{array}$ & Yes & $31.51 \%$ & $26.98 \%$ & $230(29.53 \%)$ \\
\hline- & No & $68.49 \%$ & $73.02 \%$ & $549(70.47 \%)$ \\
\hline $\begin{array}{c}\text { Spending time for } \\
\text { leisure. }\end{array}$ & Yes & $55.02 \%$ & $43.11 \%$ & $388(49.81 \%)$ \\
\hline- & No & $44.98 \%$ & $56.89 \% *$ & $391(50.19 \%)$ \\
\hline Curiosity & Yes & $31.96 \%$ & $29.91 \%$ & $242(31.07 \%)$ \\
\hline- & No & $68.04 \%$ & $70.09 \%$ & $537(68.93 \%)$ \\
\hline Other & Yes & $14.84 \%$ & $10.26 \%$ & $100(12.84 \%)$ \\
\hline- & No & $85.16 \%$ & $89.74 \%$ & $679(87.16 \%)$ \\
\hline - & & & \\
\hline -value $<0.05$ & & & \\
\hline
\end{tabular}

Participants had $\mathrm{m}=5.12(\mathrm{SD}=2.92)$ social media accounts. The number of days that each social media app was used per week differed, with WhatsApp used the most $(\mathrm{m}=$ $6.13, \mathrm{SD}=2.10)$, followed by Snapchat $(\mathrm{m}=5.33, \mathrm{SD}=2.65)$, Instagram $(\mathrm{m}=4.63, \mathrm{SD}=2.84)$, YouTube $(\mathrm{m}=4.52, \mathrm{SD}=$ $2.71)$, and Twitter $(\mathrm{m}=3.38, \mathrm{SD}=2.94)$. Facebook and LinkedIn were used by some participants with non-normal data distribution of median of 0 , minimum of 0 , and a maximum of 7 days.

The personal and professional reasons for using social media, in general, are shown in Tables $\mathbf{2}$ and 3. Table $\mathbf{4}$ displays some of the main attitudes the participants held about social media. Table 5 illustrates the participants' opinions and attitudes toward specific professional uses of social media. All these tables also display the differences between students and intern/dentists as determined with the Chi-squared test.

Table 3. Professional reasons for using social media.

\begin{tabular}{|c|c|c|c|c|}
\hline \multirow[t]{2}{*}{-} & \multirow{2}{*}{-} & \multicolumn{2}{|c|}{ Current Position } & \multirow{2}{*}{\begin{tabular}{|c} 
Total n (\%) \\
-
\end{tabular}} \\
\hline & & $\begin{array}{c}\text { Dental } \\
\text { Student } \\
(\%)\end{array}$ & $\begin{array}{c}\text { Intern/ } \\
\text { Dentist (\%) }\end{array}$ & \\
\hline $\begin{array}{c}\text { For finding dental } \\
\text { information (learning) }\end{array}$ & Yes & $80.14 \%$ & $78.89 \%$ & $620(79.59 \%)$ \\
\hline- & No & $19.86 \%$ & $21.11 \%$ & $159(20.41 \%)$ \\
\hline $\begin{array}{l}\text { Watching clinical } \\
\text { procedures (videos or } \\
\text { live) for learning }\end{array}$ & Yes & $81.51 \%$ & $79.18 \%$ & $627(80.49 \%)$ \\
\hline- & No & $18.49 \%$ & $20.82 \%$ & $152(19.51 \%)$ \\
\hline $\begin{array}{c}\text { Learning from other } \\
\text { professionals (peer } \\
\text { learning) }\end{array}$ & Yes & $60.73 \%$ & $61.58 \%$ & $476(61.1 \%)$ \\
\hline- & No & $39.27 \%$ & $38.42 \%$ & $303(38.9 \%)$ \\
\hline $\begin{array}{l}\text { Virtual meetings with } \\
\text { other students/faculty }\end{array}$ & Yes & $28.54 \%$ & $28.74 \%$ & $223(28.63 \%)$ \\
\hline- & No & $71.46 \%$ & $71.26 \%$ & $556(71.37 \%)$ \\
\hline $\begin{array}{l}\text { Sharing dental content } \\
\text { such as files, pictures, } \\
\text { x-rays, and other }\end{array}$ & Yes & $50 \%$ & $48.68 \%$ & $385(49.42 \%)$ \\
\hline- & No & $50 \%$ & $51.32 \%$ & $394(50.58 \%)$ \\
\hline $\begin{array}{l}\text { Developing an e- } \\
\text { portfolio for future } \\
\text { employment }\end{array}$ & Yes & $22.37 \%$ & $20.23 \%$ & $167(21.44 \%)$ \\
\hline- & No & $77.63 \%$ & $79.77 \%$ & $612(78.56 \%)$ \\
\hline $\begin{array}{c}\text { Communicate with } \\
\text { patients }\end{array}$ & Yes & $55.71 \%$ & $48.97 \%$ & $411(52.76 \%)$ \\
\hline- & No & $44.29 \%$ & $51.03 \%$ & $368(47.24 \%)$ \\
\hline $\begin{array}{c}\text { Increase well-being } \\
\text { (such as self-esteem) by } \\
\text { positive feedback }\end{array}$ & Yes & $37.21 \%$ & $30.21 \%$ & $266(34.15 \%)$ \\
\hline- & No & $62.79 \%$ & $69.79 \% *$ & $513(65.85 \%)$ \\
\hline Other & Yes & $14.61 \%$ & $10.85 \%$ & $101(12.97 \%)$ \\
\hline- & No & $85.39 \%$ & $89.15 \%$ & $678(87.03 \%)$ \\
\hline
\end{tabular}

Three tables display the professionalism of dental students and intern/dentists in terms of using social media. Table $\mathbf{6}$ shows the professionalism guidelines participants were subject to when using social media, if any. Table 7 displays the percentages of participants who rated some statements as 
Table 4. Attitudes toward social media in general.

\begin{tabular}{|c|c|c|c|c|}
\hline- & - & \multicolumn{2}{|c|}{ Current Position } & Total n (\%) \\
\hline- & - & Dental Student (\%) & Intern/ Dentist (\%) & - \\
\hline I use my real name on the social media platform that I use the most. & Yes & $84.47 \%$ & $76.54 \%$ & $631(81 \%)$ \\
\hline 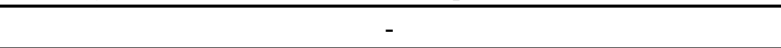 & No & $15.53 \%$ & $23.46 \% *$ & $148(19 \%)$ \\
\hline I feel that I am addicted to at least one social media platform. & Yes & $64.61 \%$ & $57.18 \%$ & $478(61.36 \%)$ \\
\hline- & No & $35.39 \%$ & $42.82 \% *$ & $301(38.64 \%)$ \\
\hline I feel happy when I use social media. & Yes & $69.86 \%$ & $60.7 \%$ & $513(65.85 \%)$ \\
\hline- & No & $30.14 \%$ & $39.3 \% *$ & $266(34.15 \%)$ \\
\hline Social media keeps me awake and sleep poorly. & Yes & $48.63 \%$ & $33.72 \%$ & $328(42.11 \%)$ \\
\hline- & No & $51.37 \%$ & $66.28 \% *$ & $451(57.89 \%)$ \\
\hline Social media wastes my time. & Yes & $61.19 \%$ & $50.15 \%$ & $439(56.35 \%)$ \\
\hline- & No & $38.81 \%$ & $49.85 \% *$ & $340(43.65 \%)$ \\
\hline
\end{tabular}

Table 5. Participants' opinions/attitudes toward professionalism when using social media.

\begin{tabular}{|c|c|c|c|c|}
\hline- & - & \multicolumn{2}{|c|}{ Current Position } & Total n (\%) \\
\hline- & - & Dental Student (\%) & Intern/ Dentist (\%) & - \\
\hline I present myself on social media as a dentist or dental student. & Yes & $63.93 \%$ & $63.05 \%$ & $495(63.54 \%)$ \\
\hline- & No & $36.07 \%$ & $36.95 \%$ & $284(36.46 \%)$ \\
\hline $\begin{array}{l}\text { I have different accounts for personal and professional use (on at least one social } \\
\text { media platform). }\end{array}$ & Yes & $36.76 \%$ & $35.48 \%$ & $282(36.2 \%)$ \\
\hline- & No & $63.24 \%$ & $64.52 \%$ & $497(63.8 \%)$ \\
\hline $\begin{array}{l}\text { I believe that it is better to keep my personal life separate from my professional life on } \\
\text { social media. }\end{array}$ & Yes & $62.56 \%$ & $63.64 \%$ & $491(63.03 \%)$ \\
\hline- & No & $37.44 \%$ & $36.36 \%$ & $288(36.97 \%)$ \\
\hline $\begin{array}{l}\text { Do you think it is appropriate to be friends on social media with workplace dental staff } \\
\text { (university staff, dental assistant, colleagues, work supervisors, etc.)? }\end{array}$ & Yes & $69.63 \%$ & $65.69 \%$ & $529(67.91 \%)$ \\
\hline- & No & $30.37 \%$ & $34.31 \%$ & $250(32.09 \%)$ \\
\hline Do you think it is appropriate to be friends on social media with your patients? & Yes & $43.38 \%$ & $34.02 \%$ & $306(39.28 \%)$ \\
\hline- & No & $56.62 \%$ & $65.98 \% *$ & $473(60.72 \%)$ \\
\hline
\end{tabular}

$* P$-value $<0.05$

Table 6. Professionalism guidelines when using social media.

\begin{tabular}{|c|c|c|c|c|}
\hline- & - & \multicolumn{2}{|c|}{ Current Position } & Total n (\%) \\
\hline- & - & Dental Student (\%) & Intern/ Dentist (\%) & - \\
\hline Guidelines that make me appear professional to the public. & Yes & $57.08 \%$ & $59.24 \%$ & $452(58.02 \%)$ \\
\hline- & No & $42.92 \%$ & $40.76 \%$ & $327(41.98 \%)$ \\
\hline University or workplace social media guidelines or policy. & Yes & $48.63 \%$ & $46.63 \%$ & $372(47.75 \%)$ \\
\hline- & No & $51.37 \%$ & $53.37 \%$ & $407(52.25 \%)$ \\
\hline Religious guidelines or rules. & Yes & $37.21 \%$ & $37.83 \%$ & $292(37.48 \%)$ \\
\hline- & No & $62.79 \%$ & $62.17 \%$ & $487(62.52 \%)$ \\
\hline I do not have any professionalism guidelines for using social media. & Yes & $31.74 \%$ & $25.51 \%$ & $226(29.01 \%)$ \\
\hline- & No & $68.26 \%$ & $74.49 \%$ & $553(70.99 \%)$ \\
\hline
\end{tabular}

unprofessional. Table $\mathbf{8}$ illustrates the attitudes toward using social media for business and marketing purposes and the differences between students and interns/dentists, where the differences were determined using the $C h i$-squared test.

\section{DISCUSSION}

Our study that investigated dental students and dentists in
Saudi Arabia showed that the most frequently used social media among our sample were WhatsApp, Snapchat, and Instagram, while the least used were Facebook and LinkedIn. $4 / 5^{\text {th }}$ of the respondents use social media for educational purposes, such as learning new dental information or watching clinical procedures. Also, about half of the respondents use social media to communicate with patients. Two out of three tie their 
Table 7. Behaviors believed to be an unprofessional use of social media.

\begin{tabular}{|c|c|c|c|c|}
\hline- & - & \multicolumn{2}{|c|}{ Current Position } & Total n (\%) \\
\hline- & - & Dental Student (\%) & Intern/ Dentist (\%) & - \\
\hline Posting information/photos about a patient without the patient's permission. & Yes & $68.72 \%$ & $74.49 \%$ & $555(71.25 \%)$ \\
\hline 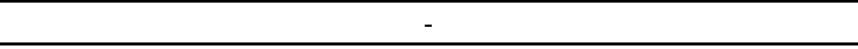 & No & $31.28 \%$ & $25.51 \%$ & $224(28.75 \%)$ \\
\hline Posting information/photos about a patient with the patient's permission. & Yes & $36.53 \%$ & $32.55 \%$ & $271(34.79 \%)$ \\
\hline- & No & $63.47 \%$ & $67.45 \%$ & $508(65.21 \%)$ \\
\hline Attitudes of superiority or high ego levels. & Yes & $49.77 \%$ & $52.79 \%$ & $398(51.09 \%)$ \\
\hline- & No & $50.23 \%$ & $47.21 \%$ & $381(48.91 \%)$ \\
\hline Critical comments about university staff, a student, or a dental colleague. & Yes & $48.86 \%$ & $53.67 \%$ & $397(50.96 \%)$ \\
\hline- & No & $51.14 \%$ & $46.33 \%$ & $382(49.04 \%)$ \\
\hline Critical comments about university or place of work as an organization. & Yes & $39.73 \%$ & $41.06 \%$ & $314(40.31 \%)$ \\
\hline- & No & $60.27 \%$ & $58.94 \%$ & $465(59.69 \%)$ \\
\hline Using bad words (swearing). & Yes & $61.19 \%$ & $71.55 \%$ & $512(65.73 \%)$ \\
\hline 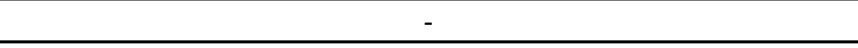 & No & $38.81 \%$ & $28.45 \% *$ & $267(34.27 \%)$ \\
\hline Comments about scientifically controversial issues. & Yes & $26.26 \%$ & $24.93 \%$ & $200(25.67 \%)$ \\
\hline- & No & $73.74 \%$ & $75.07 \%$ & $579(74.33 \%)$ \\
\hline
\end{tabular}

$* P$-value $<0.05$

Table 8. Attitudes toward using social media for business and marketing purposes.

\begin{tabular}{|c|c|c|c|c|}
\hline- & - & \multicolumn{2}{|c|}{ Current Position } & Total n (\%) \\
\hline- & - & Dental Student (\%) & Intern/ Dentist (\%) & - \\
\hline I use social media for marketing myself as a dentist or dental student. & Yes & $47.95 \%$ & $33.72 \%$ & $325(41.72 \%)$ \\
\hline- & No & $52.05 \%$ & $66.28 \% *$ & $454(58.28 \%)$ \\
\hline I use social media to market my dental college or my dental place of work. & Yes & $37.21 \%$ & $38.71 \%$ & $295(37.87 \%)$ \\
\hline- & No & $62.79 \%$ & $61.29 \%$ & $484(62.13 \%)$ \\
\hline $\begin{array}{l}\text { I believe that using social media (in general) is important to obtain new patients } \\
\text { and increase my market value. }\end{array}$ & Yes & $62.33 \%$ & $53.08 \%$ & 454 (58.28\%) \\
\hline- & No & $37.67 \%$ & $46.92 \% *$ & $325(41.72 \%)$ \\
\hline $\begin{array}{l}\text { I believe that posting before and after dental cases on social media is important to } \\
\text { obtain new patients and increase my market value. }\end{array}$ & Yes & $68.26 \%$ & $58.94 \%$ & $500(64.18 \%)$ \\
\hline- & No & $31.74 \%$ & $41.06 \% *$ & $279(35.82 \%)$ \\
\hline $\begin{array}{l}\text { Using social media for marketing in dentistry is better than conventional } \\
\text { marketing. }\end{array}$ & Yes & $64.84 \%$ & $61 \%$ & $492(63.16 \%)$ \\
\hline- & No & $35.16 \%$ & $39 \%$ & $287(36.84 \%)$ \\
\hline $\begin{array}{l}\text { Posting unprofessional materials may affect the dentist's/dental student's } \\
\text { reputation. }\end{array}$ & Yes & $63.93 \%$ & $61.58 \%$ & $490(62.9 \%)$ \\
\hline- & No & $36.07 \%$ & $38.42 \%$ & $289(37.1 \%)$ \\
\hline
\end{tabular}

social media presence to their profession (dental student or dentist), and less than the half think it is OK to befriend their patients on social media. Around one-third do not have any professionalism guidelines for using social media, and our results also showed that one-third of the participants have posted patient information online without the patient's permission. Despite the tie to their profession, less than half use social media to market themselves as dental students or dentists. When comparing dental students with interns/dentists, we found very little difference between their answers in most areas; however, in multiple questions about using social media as a marketing tool in dentistry, differences were found.

Our results regarding the use of multiple social media accounts by both dental students and dentists were similar to the previous studies [13]. However, the results regarding the most commonly used social media platform were greatly different than previous international and local studies. For example, many previous studies ranked Facebook as the most commonly used social media platform among dental students and dentists in several countries, including the United States, the United Kingdom, and South Africa [6 - 8, 11, 12]. The only previous Saudi study among medical students had shown that YouTube and Twitter were the favorite platforms [14]. On the other hand, our results showed that Facebook is among the least used social media platform among the target population. Instead, WhatsApp, Snapchat, and Instagram were the most commonly used. The reasons for the differences between our results and previous studies are not clear. However, it is suggested that the differences might be due to cultural variations in the United Kingdom, the United States, and South Africa studies, and with regard to the differences from the 
previous Saudi study, could be a result of the different nature of cases and treatments between the medical and dental professions. Given our results, WhatsApp, Snapchat, and Instagram could be the main platforms to target for the inclusion of dental educational material, and should be the focus for fabricating guidelines for the proper use of these platforms by dental students and dentists in Saudi Arabia, based on the unique nature of each application.

Previous studies have marginally mentioned some of the areas where dental students and dentists use social media for educational and professional uses, including learning clinical skills $[9,10]$, facilitating communication between students and instructors, communicating with patients, and enhancing educational materials $[4,12]$. A study highlighted the use of YouTube as major platform for learning using flipped classroom in Korea [19], while another Saudi study explained how social media can be used to deliver oral hygiene instruction to the patient [20] Our results were similar to previous studies but also added the factor of social media being used by the majority of our respondents mainly for seeking out new dental information, watching clinical procedures, and learning from others, as well as other usages that are not as common. Also, in our study, we found that these professional uses were not exclusive to students but were also found among interns and dentists currently in practice, with no significant differences between them. This shows that, when used in a proper manner, social media's benefits extend from the college years into a dentist's professional life. This could highlight the potential advantages of social media for dental students as well as for dentists' continuing education.

Some earlier studies noted the lack of knowledge among dental students with regard to legal regulations that could be pertinent and with regard to general professional behavior when using social media in a professional capacity [8]. Our study supports these findings, showing that around half of the students and the practicing dentists, as well do not follow university or workplace guidelines when using social media. Further, around one-third of our respondents reported not having any professionalism guidelines, which raises a red flag concerning social media use by these health care workers and whether it is done in a non-harmful manner. In fact, this was made clear in our study where only about one-third of both dental students and dentists (with no significant differences) believed that it is a problem to post patient information and photos without the patient's permission. Furthermore, around half of our respondents considered egotistic displays, criticism of colleagues, and critical comments about dental organizations to be acceptable behavior. This clearly demonstrates the gap in professional guidelines for both students and practicing dentists in regard to communicating with patients and regarding their careers when using social media. This was also was noticed in another study where dental students in the UK were not aware of the definition of professional [21]. More importantly, this shows that there is a major breach to patient' confidentiality, which is a major flaw in using social media and should be handled seriously. It is suggested that this situation is a result of the recent emergence of social media and that there was not enough educational material to be included in dental ethics curricula for students or in practicing dentists' continuing education programs. Despite the announcement of some legal consequences of certain unethical social media actions in Saudi Arabia by the Saudi government, it seems that there is little awareness of these governmental guidelines for the use of social media. Also, according to the best of our knowledge, there were no official guidelines to use social media have been given to the students in the investigated dental school, which might be different than other dental schools in other countries. Thus, it is important to include such modules in dental student and dentist educational materials and to call for more organizational policies on a national level around the professional use of social media in order to preserve patients' and dentists' rights.

From another perspective, the results of previous studies in relation to social media use for marketing purposes were controversial in terms of differences between dental students and dentists and between participants from different countries, including the United States, the United Kingdom, and South Africa, as detailed in the introduction [11 - 13]. Our study indicated that around half the dental students use social media for marketing, in comparison to around one-third of interns and dentists who do the same. This result is considerably lower than that found in the United States [12], but it is higher than what has been found in South Africa [11]. Nevertheless, more than half of the dental students and dentists in our study believe that social marketing might be more effective than conventional marketing. Also, many participants (though more among dental students) believe that posting before and after treatment cases on their social media accounts has high marketing value for them. This is important, as it should be linked to the lack of professional knowledge and beliefs about using social media found among both dental students and practicing dentists in Saudi Arabia.

This study has several strengths; it is the first study in Saudi Arabia to assess the current usage and attitudes regarding professional practice in the use of social media among dental students and dentists in Saudi Arabia. Also, it included a relatively large sample size in comparison to the previous studies, and data were taken from three major cities in Saudi Arabia. However, there were also some limitations, including a self-reported data collection method and a convenience sample.

\section{CONCLUSION}

In conclusion, social media is being heavily used by dental students and dentists in Saudi Arabia, with WhatsApp, Snapchat, and Instagram being the most commonly used on a regular basis. However, there are many concerns about dental students and dentists using social media unprofessionally and in ways that might jeopardize a patient's privacy and their confidential information. Our recommendation is to use social media for educational purposes, similar to the way they are commonly used by the target population, and to foster professional behaviors by teaching professionalism guidelines in continuing education materials.

\section{LIST OF ABBREVIATIONS}

$\begin{array}{lll}\text { UK } & = & \text { United Kingdom } \\ \text { KSA } & = & \text { Kingdom of Saudi Arabia }\end{array}$




$\begin{array}{lll}\mathbf{m} & = & \text { Mean } \\ \text { SD } & = & \text { Standard Deviation }\end{array}$

SD $\quad=\quad$ Standard Deviation

\section{ETHICS APPROVAL AND CONSENT TO PARTI- CIPATE}

This study was ethically reviewed and approved by the Faculty of Dentistry Institutional Review Board, Umm Al-Qura University Saudia Arabia with application number (102-18).

\section{HUMAN AND ANIMAL RIGHTS}

No animals were used in this research. All research procedures followed were in accordance with the ethical standards of the committee responsible for human experimentation (institutional and national), and with the Helsinki Declaration of 1975, as revised in 2008.

\section{CONSENT FOR PUBLICATION}

All participants signed the study consent before participating in the study.

\section{CONFLICT OF INTEREST}

The authors declare no conflict of interest, financial or otherwise.

\section{ACKNOWLEDGEMENTS}

We would like to thank Raad Abu-harbah, Donya Ganboa, and Rawan Abujabal for helping in data collection.

\section{REFERENCES}

[1] Oxford English Dictionary. Social Media 2018 [cited 2018 Dec 27]; Available from: https://en.oxforddictionaries.com/definition/ social_ media

[2] Kaplan AM, Haenlein M. Users of the world, unite! The challenges and opportunities of social media. Bus Horiz 2010; 53(1): 59-68. [http://dx.doi.org/10.1016/j.bushor.2009.09.003]

[3] Osman A, Wardle A. Is it time for medicine to update its Facebook status? BMJ 2011; 343: d6334.

[http://dx.doi.org/10.1136/bmj.d6334] [PMID: 21971167]

[4] Javed MW, Bhatti R. Usage of social media by medical and dental students at Nishtar Medical College, Multan, Pakistan. J Hosp Librariansh 2015; 15(1): 53-64.

[http://dx.doi.org/10.1080/15323269.2015.982031]

[5] Chib A, Cheong YJ, Lee LCL, Ng CHC, Tan CK, Vlv K. The hope of mobile phones in Indian rural healthcare. J Health Inform Dev Ctries 2012; 6(1): 406-21.

[6] Peluchette J, Karl K. Social networking profiles: An examination of student attitudes regarding use and appropriateness of content. Cyberpsychol Behav 2008; 11(1): 95-7.

[http://dx.doi.org/10.1089/cpb.2007.9927] [PMID: 18275320]

[7] Arnett MR, Christensen HL, Nelson BA. A school-wide assessment of social media usage by students in a US dental school. Br Dent J 2014; 217(9): 531-5.

[http://dx.doi.org/10.1038/sj.bdj.2014.956] [PMID: 25377826]

[8] Kenny P, Johnson IG. Social media use, attitudes, behaviours and perceptions of online professionalism amongst dental students. $\mathrm{Br}$ Dent J 2016; 221(10): 651-5.

[http://dx.doi.org/10.1038/sj.bdj.2016.864] [PMID: 27857111]

[9] Parkinson JW, Turner SP. Use of social media in dental schools: Pluses, perils, and pitfalls from a legal perspective. J Dent Educ 2014; 78(11): 1558-67. [PMID: 25362698]

[10] McAndrew M, Johnston AE. The role of social media in dental education. J Dent Educ 2012; 76(11): 1474-81. [PMID: 23144483]

[11] Snyman L, Visser JH. The adoption of social media and social media marketing by dentists in South Africa. SADJ 2014; 69(6): 258-264, 260-264.

[PMID: 26548200]

[12] Henry RK, Molnar A, Henry JC. A survey of US dental practices' use of social media. J Contemp Dent Pract 2012; 13(2): 137-41.

[http://dx.doi.org/10.5005/jp-journals-10024-1109] [PMID: 22665737]

[13] Parmar N, Dong L, Eisingerich AB. Connecting with your dentist on Facebook: Patients' and dentists' attitudes towards social media usage in dentistry. J Med Internet Res 2018; 20(6): e10109. [http://dx.doi.org/10.2196/10109] [PMID: 29959108]

[14] Alsuraihi AK, Almaqati AS, Abughanim SA, Jastaniah NA. Use of social media in education among medical students in Saudi Arabia. Korean J Med Educ 2016; 28(4): 343-54.

[http://dx.doi.org/10.3946/kjme.2016.40] [PMID: 27907981]

[15] Barlow CJ, Morrison S, Stephens HO, Jenkins E, Bailey MJ, Pilcher D. Unprofessional behaviour on social media by medical students. Med J Aust 2015; 203(11): 439

[http://dx.doi.org/10.5694/mja15.00272] [PMID: 26654611]

[16] Kumari A, Ali K, Mahadevamurthy M, Ali H. Use of social media among dental students of Farooqia Dental College, Mysore: A study. In: International Conference on Open Access-Scholarly Communication Reincarnated: A Futuristic Approach; Bangalore. 2013; pp. 377-88.

[17] White J, Kirwan P, Lai K, Walton J, Ross S. 'Have you seen what is on Facebook?' The use of social networking software by healthcare professions students. BMJ Open 2013; 3(7): e003013. [http://dx.doi.org/10.1136/bmjopen-2013-003013] [PMID: 23883886]

[18] Wyatt LA, Mallonee LF, McCann AL, Campbell PR, Schneiderman ED, DeWald JP. Exploring interactions between dental hygiene faculty and current undergraduate dental hygiene students on Facebook. Canadian J Dent Hyg 2016; 50(1): 7-14.

[19] Seo CW, Cho AR, Park JC, Cho HY, Kim S. Dental students' learning attitudes and perceptions of YouTube as a lecture video hosting platform in a flipped classroom in Korea. J Educ Eval Health Prof 2018; 15: 24

[http://dx.doi.org/10.3352/jeehp.2018.15.24] [PMID: 30317831]

[20] El Tantawi M, Bakhurji E, Al-Ansari A, AlSubaie A, Al Subaie HA, AlAli A. Indicators of adolescents' preference to receive oral health information using social media. Acta Odontol Scand 2019; 77(3): 213-8. Epub ahead of print

[http://dx.doi.org/10.1080/00016357.2018.1536803] [PMID: 30632 864]

[21] Knott PN, Wassif HS. Older and wiser? First year BDS graduate entry students and their views on using social media and professional practice. Br Dent J 2018; 225(5): 437-40.

[http://dx.doi.org/10.1038/sj.bdj.2018.745] [PMID: 30168814]

\section{(C) 2019 Aboalshamat et al.}

This is an open access article distributed under the terms of the Creative Commons Attribution 4.0 International Public License (CC-BY 4.0), a copy of which is available at: (https://creativecommons.org/licenses/by/4.0/legalcode). This license permits unrestricted use, distribution, and reproduction in any medium, provided the original author and source are credited. 